\title{
Laser melting treatment of Ni-P surface alloys on mild steel: Influence of initial coating thickness and laser scanning rate $^{(\bullet)}$
}

\author{
M.C. García-Alonso ${ }^{(*)}$, V. López ${ }^{(*)}$, M.L. Escudero $^{(*)}$ and A. Macías $^{(* *)}$

\begin{abstract}
Different thickness Ni-P coatings deposited on mild steel are submitted to laser surface melting at different scanning rates. The microstructure of the alloys is characterized by optical and scanning electron microscopy and microprobe analysis. It is shown that both the initial coating thickness and the laser scanning rate have an influence on the shape, extent and size of the different structures resulting from the solidification process. Thus, when the laser scanning rate increases a progressive refinement of the structure takes place that could even totally block the dendritic growth produced during solidification for a high initial coating thickness.
\end{abstract}

Keywords: Ni-P coating. Microstructure. Laser. Melting. Mild steel.

\section{Fusión con láser de recubrimientos de $\mathrm{Ni}-\mathrm{P}$ sobre acero microaleado: Influencia del espesor de recubrimiento y velocidad de barrido del láser}

\begin{abstract}
Resumen Recubrimientos de Ni-P, con distinto espesor, depositados sobre un acero microaleado fueron tratados con láser a diferentes velocidades de barrido. La microestructura, tanto del recubrimiento como del acero base, ha sido caracterizada por microscopía óptica y electrónica y por microanálisis. En el proceso de solidificación se han obtenido distintas estructuras que varían en cuanto a la forma, extensión y tamaño dependiendo del espesor inicial de recubrimiento y de la velocidad de barrido del haz láser. A medida que la velocidad del haz aumenta, se produce un refinamiento progresivo de la microestructura dendrítica y, en casos extremos de alto espesor de recubrimiento y velocidades grandes, este crecimiento dendrítico se bloquea.
\end{abstract}

Palabras clave: Recubrimiento Ni-P. Microestructura. Laser. Fusión. Acero suave.

\section{INTRODUCTION}

The corrosion of exposed metals usually starts at local small cathodic and anodic areas associated to metal microstructure, as grain boundaries, impurities at the metal surface, crystallographical defects... The amorphous alloys could combine the

$(\bullet \quad$ Trabajo recibido el día 1 de octubre de 1996.

(*) Centro Nacional de Investigaciones Metalúrgicas (CSIC). Avda. de Gregorio del Amo, 8. E-28040-Madrid (España).

(**) Instituto de Ciencias de la Construcción Eduardo Torroja (CSIC). c/ Serrano Galvache, s/n. E-28033-Madrid (España). ductility and conductivity of metals with the great resistance and chemical inertia of glasses which lack crystalline structure (1).

The solidification microstructure depends especially on the solidification rate and on the material composition (2). Thus the addition of a non metallic element, as phosphorous, in a proportion equal or higher than 20 at. wt. \% leads to amorphous alloys ( 3 and 4 ). In the rapid solidification technics, the cooling rate is a function of both the sample thickness and the characteristics of the contact between the sample and the cooling substrate. In practice, the high cooling rates needed to get an amorphous structure $\left(>10^{5} \mathrm{Ks}^{-1}\right)$ are only possible for low thickness alloys. Others 
technologies for manufacturing amorphous alloys are based on the predeposition of an amorphous coating on a metallic substrate with a low degree of dilution. Corrosion resistant surfaces with high mechanical performances are obtained by this procedure (5). During the processing of surface alloys, high levels of residual stresses may be introduced in the coating that can lead to cracking of various forms; clearly for the satisfactory protection of the substrate, the cracking of the coating must be kept to a minimum. Laser surface melting offers an attractive means of achieving rapid solidification and the possibility of sealing cracks in predeposited amorphous alloys.

The objective is to obtain a surface homogeneous alloy with no cracks and a high degree of amorphicity. Different thickness electroless Ni-P layers deposited on mild steel samples are considered. These systems have been submitted to laser surface melting at different scanning rates and the resulting microstructures have been characterized.

\section{EXPERIMENTAL PROCEDURE}

\subsection{Materials}

Mild steel of the composition given in table I was used as substrate. Specimens $(70 \times 33 \times 10$ $\mathrm{mm}^{3}$ ) were coated with an electroless Ni-P layer. The phosphorous content was about $8 \mathrm{wt} \%$ and the nickel content about $92 \%$. Layers of various thicknesses were used: 45, 80, 120 and $180 \mu \mathrm{m}$.

\subsection{Laser processing}

The melting treatments were carried out using a Spectra Physics 975 model. Coated specimens were irradiated with a continuous $\mathrm{CO}_{2}$ laser having an elliptical spot of $4 \times 6 \mathrm{~mm}$, moving in the direction of the minor axis, and an output power of $3 \mathrm{~kW}$, that corresponds to an energy density of 3,980 $\mathrm{W} / \mathrm{cm}^{2}$. A black absorbing paint was used to increase the efficiency of the laser treatment. Thus, the energy absorbed by the samples was about $1,650 \mathrm{~W} / \mathrm{cm}^{2}(6)$. The scanning rates varied between 1,180 and $5,952 \mathrm{~mm} / \mathrm{min}$.

TABlE I.- Chemical composition of the mild steel substrate, $\%$

TABLA I.- Composición química del acero base, \%

\begin{tabular}{|c|c|c|c|c|c|c|c|c|c|}
\hline $\mathrm{C}$ & $\mathrm{Si}$ & $\mathrm{Mn}$ & $\mathrm{P}$ & $\mathrm{S}$ & $\mathrm{Nb}$ & $\mathrm{Ca}$ & $\mathrm{Al}$ & $\mathrm{Cr}$ & $\mathrm{Cu}$ \\
\hline .10 & .34 & 1,37 & .009 & .002 & .032 & .014 & .032 & .06 & .15 \\
\hline
\end{tabular}

\subsection{Techniques for the characterization of the microstructure}

The resulting microstructures were investigated by several techniques: optical microscopy on cross sections, after etching with a $2 \%$ nital solution, for mild steel substrate structure, and concentrated $\mathrm{HNO}_{3}$ for the Ni-P alloy structure, and scanning electron microscopy and microanalysis experiments through energy dispersion analysis of X-ray (EDX).

\section{RESULTS}

\subsection{Characterization of Ni-P electroless samples}

The carbon steel substrate microstructure is composed of ferrite grains and pearlite in bands (Fig. 1).

The electroless Ni-P deposit presents no microstructure and during the cross-section examination of the samples only a succession of layers could be observed (Fig. 2). The composition

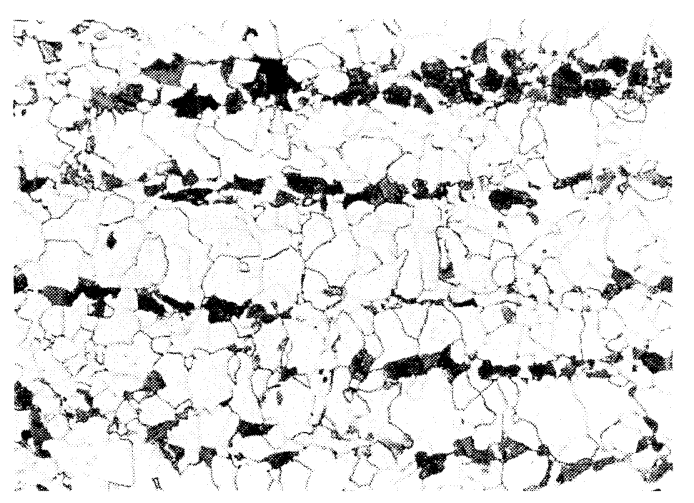

FIG. 1.- Metallographic observation of the mild steel substrate. $\times 200$.

FIG. 1.- Observación metalográfica del acero base. $\times 200$.

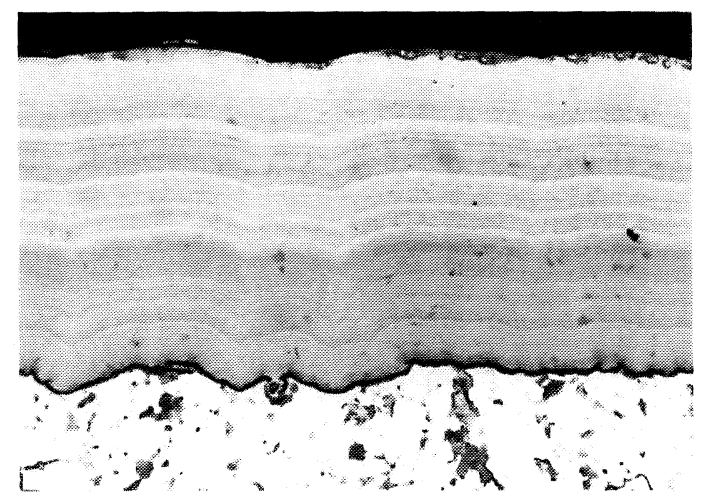

FIG. 2.- Metallographic observation of a cross section of a Ni-P coating sample $180 \mu \mathrm{m}$ thick. $\times 200$.

FIG. 2.-Observación metalográfica de una sección transversal de una probeta de Ni-P con un espesor de recubrimiento de $180 \mu \mathrm{m} . \times 200$. 
of the Ni-P alloy determined by EDX was $8 \mathrm{wt} \% \mathrm{P}$ and $92 \mathrm{wt} \% \mathrm{Ni}$. The $\mathrm{Ni}-\mathrm{P}$ coating shows longitudinal and transversal cracks due to internal stresses (Fig. 3). These stresses are generated in the absorption-desorption processes accompanying the electrodeposition reaction of nickel and in the codeposit of phosphorous that alters the crystallographic structure of nickel.

\subsection{Laser treated samples}

After optimization of the laser processing conditions, a cross-section observation of the sample reveals the existence of different zones that have been characterizated. Figure 4 shows a schematic representation of these zones.

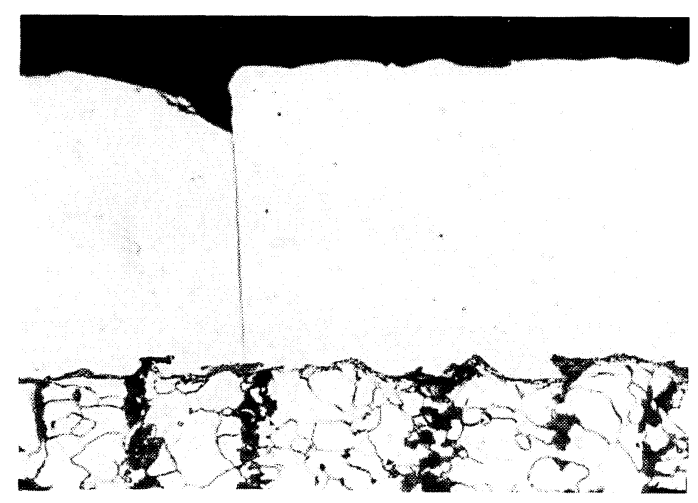

FIG. 3.- Metallographic cross section showing cracks in a $180 \mu \mathrm{m}$ thick Ni-P coating sample. $\times 200$.

FIG. 3.- Grietas en una sección transversal de una probeta de $\mathrm{Ni}$-P con un espesor de recubrimiento de $180 \mu \mathrm{m} . \times 200$.

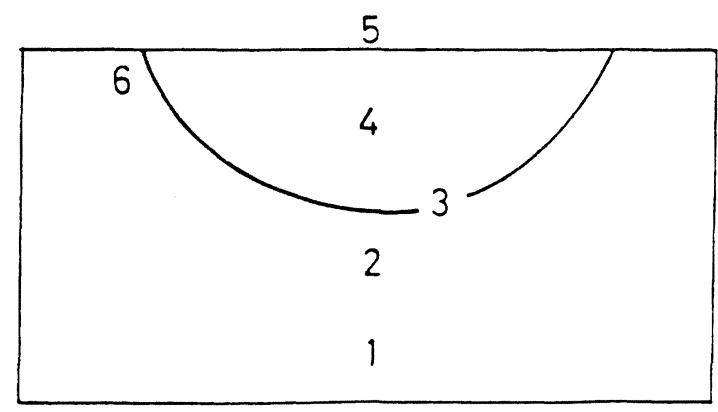

FIG. 4.- Schematic representation of the different zones found in the laser treated samples.

FIG. 4.- Representación esquemática de las diferentes zonas afectadas en una muestra tratada con láser.

\subsubsection{Steel substrate}

The steel substrate structure is composed of martensite and ferrite grains in the zone 1 of figure 4 and of martensite in the zone 2 , as can be seen in the cross section view presented in figure 5. Penetrations of melted metal appear in the steel substrate as can be seen at higher magnifications in figure 6 . These penetrations are essentially composed by phosphorous as the EDX analysis revealed.

\subsubsection{Ni-P laser treated alloy}

A strip of material without a defined structure is observed in the interface (zone 3, Fig. 4) with the steel substrate. This strip corresponds to a plane front growth as can be seen in figure 7 . The analysis of the composition of this strip shows a high iron content, some nickel proportion and no presence of phosphorous.
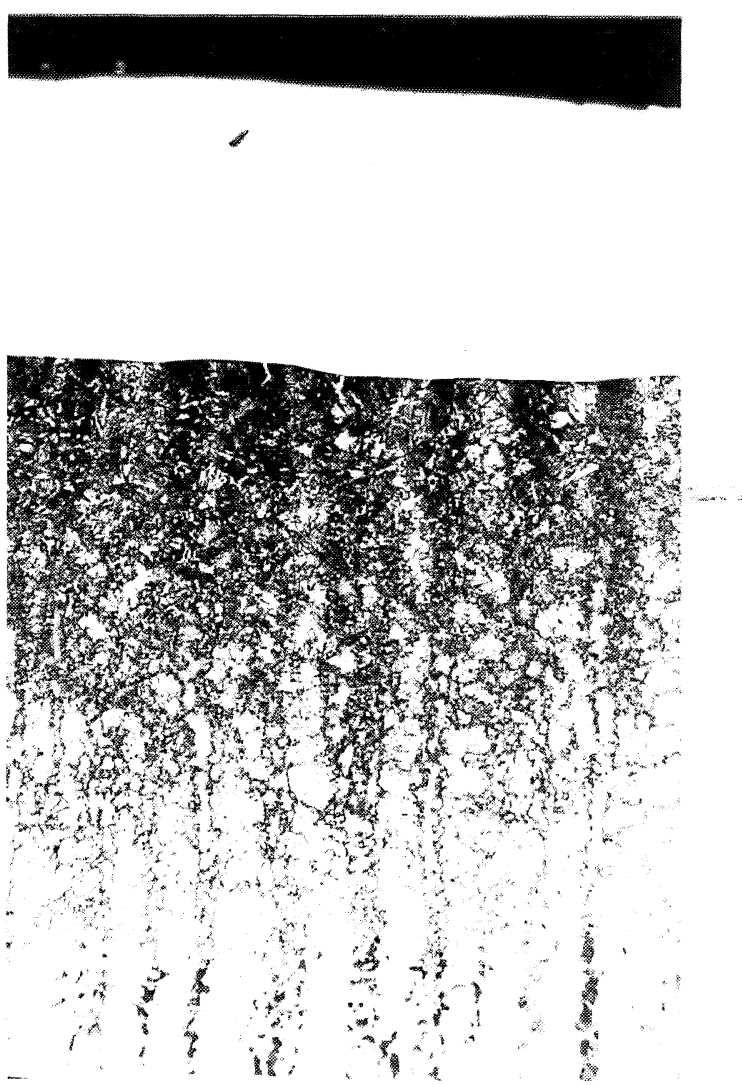

FIG. 5.- Metallographic observation on a cross section of a $180 \mu \mathrm{m}$ thick Ni-P coating laser treated at $1,180 \mathrm{~mm} / \mathrm{min}$, showing the transformation of the mild steel microstructure. $\times 100$.

FIG. 5.- Sección transversal de una probeta de $\mathrm{Ni}$-P con un espesor de $180 \mu \mathrm{m}$ tratada a una velocidad de $1.180 \mathrm{~mm} / \mathrm{min}$, en la que se muestra la transformación microestructural del acero base. $\times 100$. 


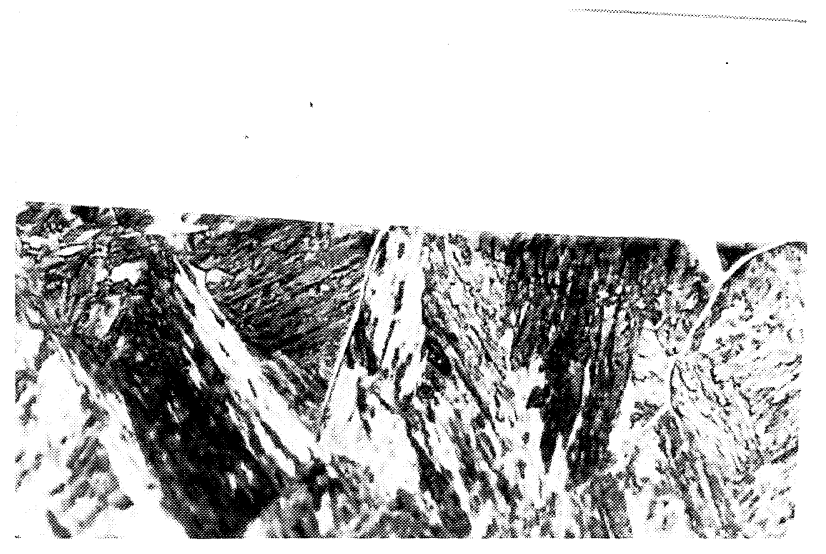

FIG. 6.- Metallographic observation of a cross section of a $45 \mu \mathrm{m}$ thick Ni-P coating laser treated at $1,180 \mathrm{~mm} / \mathrm{min}$ showing penetrations of melted metal in the steel substrate. $\times 500$.

FIG. 6.- Sección transversal de una probeta de Ni$P$ con un espesor de $45 \mu \mathrm{m}$ tratada a una velocidad de $1.180 \mathrm{~mm} / \mathrm{min}$, en la que se muestran penetraciones intergranulares del metal fundido en el acero base. $\times 500$.

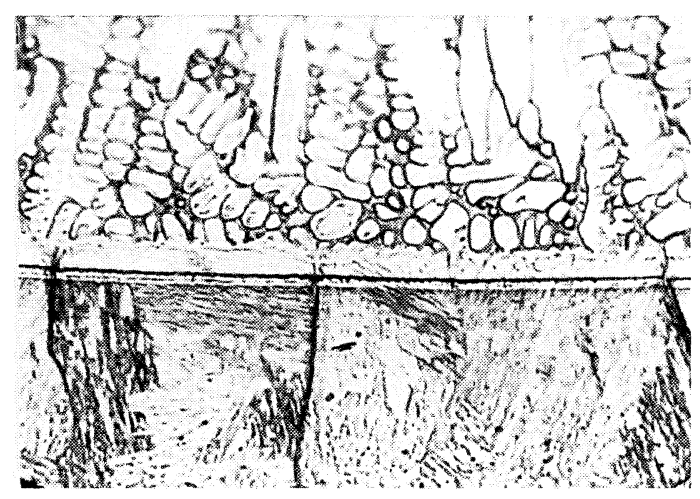

FIG. 7.- Metallographic cross section showing plane front growth in a $45 \mu \mathrm{m}$ thick Ni-P coating laser treated at $1,180 \mathrm{~mm} / \mathrm{min} . \times 500$.

FIG. 7.- Sección transversal de una probeta de $\mathrm{Ni}$-P con un espesor de $45 \mu \mathrm{m}$ tratada a una velocidad de $1.180 \mathrm{~mm} / \mathrm{min}$, en la que se muestra el frente de crecimiento plano. $\times 500$.

The rest of the Ni-P alloy (zones 4 y 5, Fig. 4) presents a dendritic solidification structure as a consequence of the laser melting (Fig. 8). The dendritic size depends on the laser processing conditions and specially on the scanning rate: the higher that rate, the smaller the dendritic size. The composition of dendrites and interdendrites areas is different. Thus, the dendrites are essentially composed by a Ni-Fe solid solution. Phosphorous does not take part in the dendritic growth being

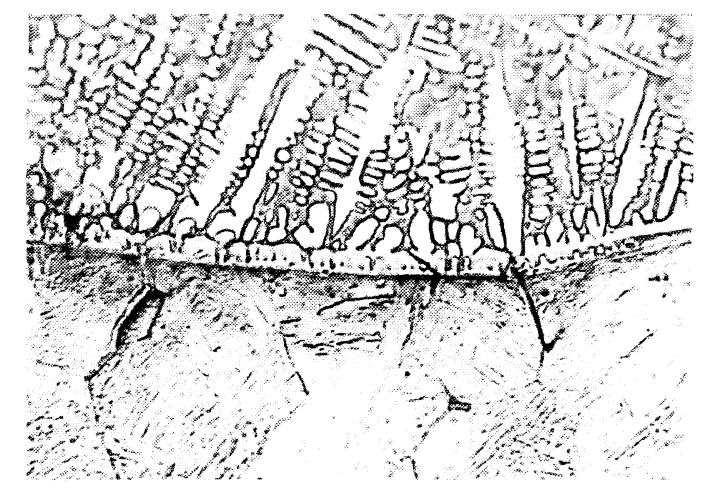

FIG. 8.- Metallographic cross section showing dendritic and interdendritic zones in a $45 \mu \mathrm{m}$ thick $\mathrm{Ni}-\mathrm{P}$ coating sample laser treated at $5,952 \mathrm{~mm} / \mathrm{min}$. $\times 500$.

FIG. 8.- Sección transversal de una probeta de Ni$P$ con un espesor de $45 \mu \mathrm{m}$ tratada a una velocidad de $5.952 \mathrm{~mm} / \mathrm{min}$, en la que se muestran las zonas dendríticas e interdendríticas del recubrimiento. $\times 500$.

rejected to the interdendritic spaces as it could be deduced from the results of the EDX analysis presented in figure 9.

A careful SEM examination of the samples reveals that the interdendritic spaces present a more complex structure (Fig. 10). Actually, the interdendritic areas are an eutectic mixture of a $\mathrm{Fe}$ $\mathrm{Ni}$ solid solution and a mixed phosphide $(\mathrm{Fe}-\mathrm{Ni})_{3} \mathrm{P}$, as could be inferred from the $\mathrm{Fe}-\mathrm{Ni}, \mathrm{Ni}-\mathrm{P}$ and $\mathrm{Fe}-\mathrm{P}$ phase diagrams (7).

The characteristics of this dendritic solidification process depend not only on the laser processing conditions but also vary with the initial

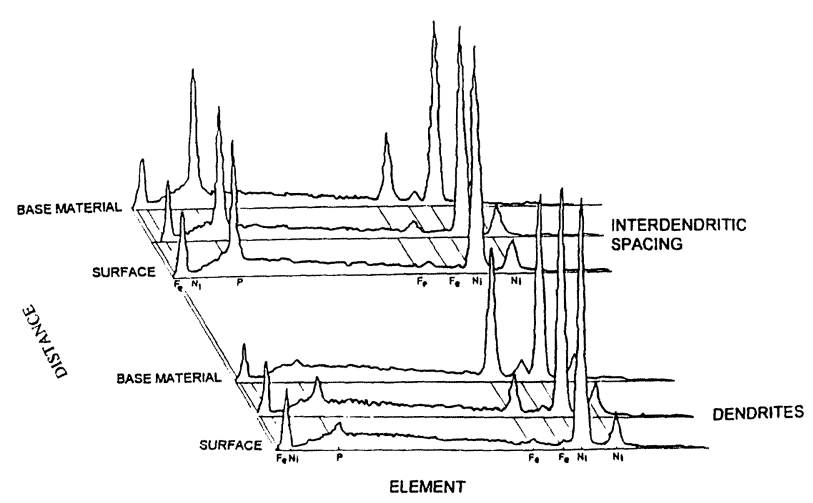

FIG. 9.- EDX analysed composition of dendritic and interdendritic zones.

FIG. 9.- Composición mediante EDX de las zonas dendríticas e interdendríticas del recubrimiento. 
coating thickness. The microstructures observed for the maximum and minimum coating thickness alloy studied and for the higher and lower scanning rate used are presented in figure 11 . For the same

FIG. 10.- SEM micrograph showing microstructure of the eutectic of interdendritic areas in $180 \mu \mathrm{m}$ thick Ni-P coating laser treated at 1,180 $\mathrm{mm} / \mathrm{min}$ sample.

FIG. 10.- Micrografía de la microestructura del eutéctico y de las áreas interdendríticas en una muestra de Ni-P con un espesor de $180 \mu$ m tratada a una velocidad de $1.180 \mathrm{~mm} / \mathrm{min}$.
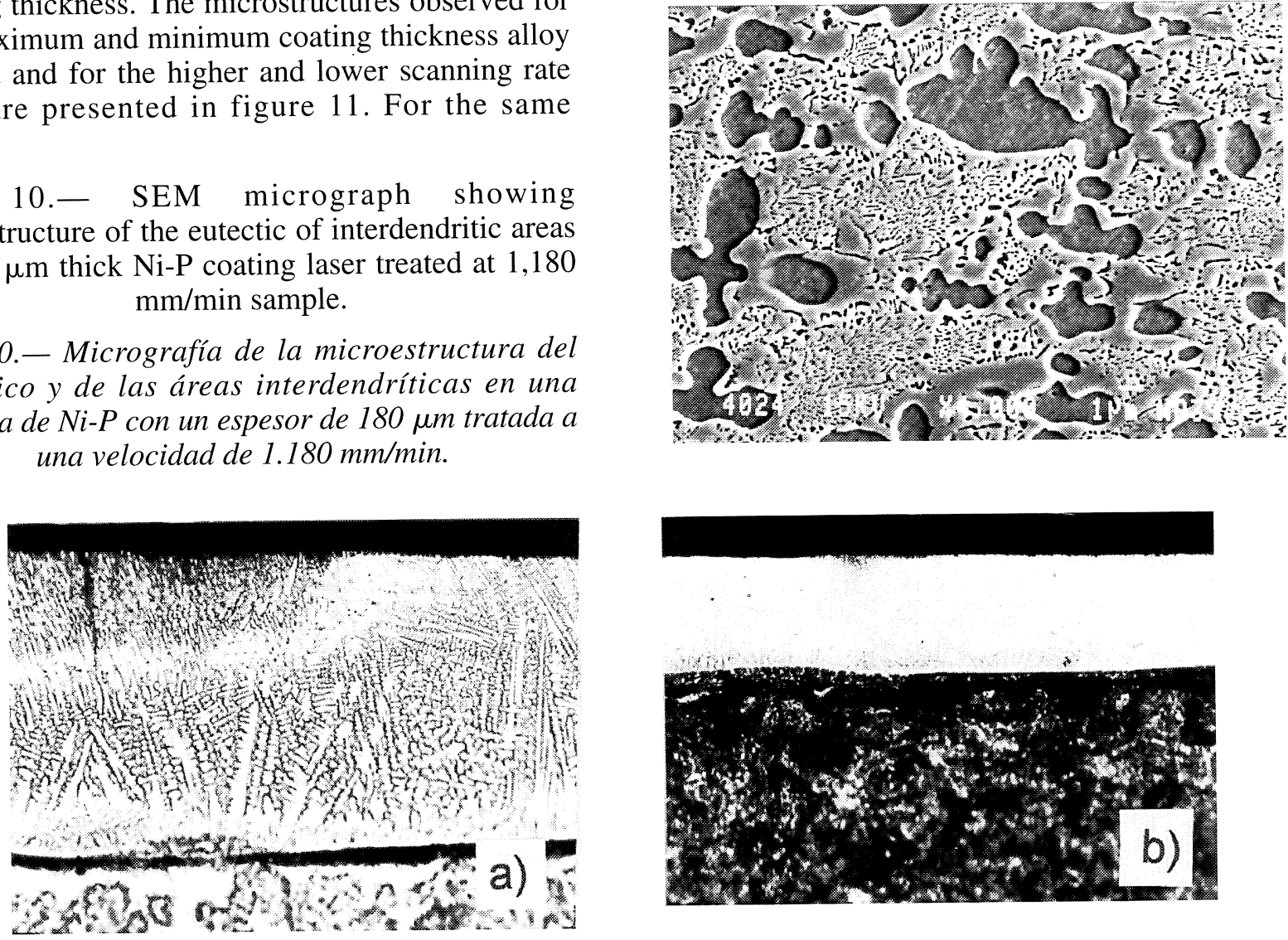

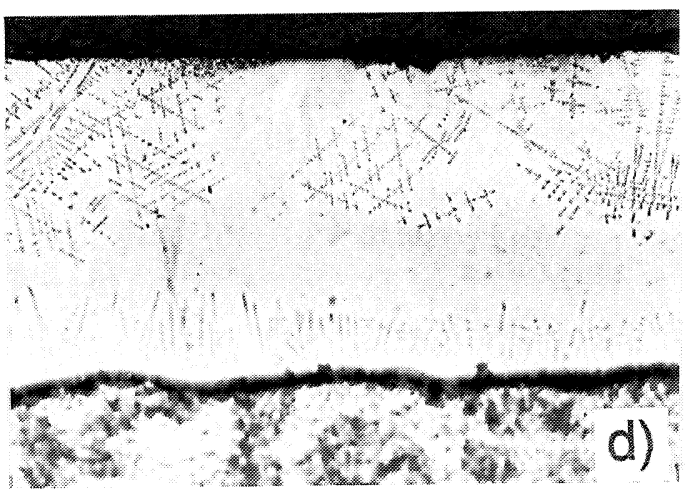

FIG. 11.- Metallographic observation on a cross section of samples: a) $45 \mu \mathrm{m}$ thick Ni-P coating laser treated at $1,180 \mathrm{~mm} / \mathrm{min}$; b) $45 \mu \mathrm{m}$ thick, $5,952 \mathrm{~mm} / \mathrm{min}$ laser rate; c) $180 \mu \mathrm{m}$ thick, $1,180 \mathrm{~mm} / \mathrm{min}$ laser rate; d) $180 \mu \mathrm{m}$ thick, $5,952 \mathrm{~mm} / \mathrm{min}$ laser rate. $\times 200$.

FIG. 11. - Secciones transversales de distintas muestras de Ni-P: a) con un espesor de 45 um tratada a una velocidad de $1.180 \mathrm{~mm} / \mathrm{min}$; b) $45 \mu \mathrm{m}$ tratada a una velocidad de $5.952 \mathrm{~mm} / \mathrm{min}$; c) $180 \mu \mathrm{m}$ tratada a una velocidad de $1.180 \mathrm{~mm} / \mathrm{min}$; d) $180 \mu \mathrm{m}$ tratada a una velocidad de $5.952 \mathrm{~mm} / \mathrm{min}$. $\times 200$. 
scanning rate, the refinement of the structure is higher as a thicker coating. The structure shown in figure $11 \mathrm{~d}$ ) is particularly interesting. For samples with the maximum $\mathrm{Ni}$-P initial coating thickness - $180 \mu \mathrm{m}$ - and laser treated at the maximum scanning rate $-5,952 \mathrm{~mm} / \mathrm{min}-$, there is no iron at all in the dendritic composition and the eutectic structure does not appear in the interdendritic areas. That is the only case in which after laser treatment, big areas of a probably amorphous material appear (Fig. 12) with the same composition of the initial Ni-P alloy. The coating is free of defects and as there is no presence of penetration nor dillution effect with substrate, the phosphorous content of the coating has not decreased.

Finally, at the heat affected zone of the laser track (zone 6, Fig.4), a globular precipitation takes place as it is possible to see in figures 13 and 14 . The globular precipitates are composed essentially by nickel with some phosphorous. As the temperature reached at the borders of the laser track is not high enough to melt the material, this process must be a solid state transformation. Two samples of different thickness were heated up to a temperature a little below their melting point and left to cool to prove this hypothesis. The SEM examination of both samples reveals a general globular precipitation similar to that shown in figure 14.

It should be mentioned that although the initial cracks of Ni-P amorphous alloy are sealed in the laser induced melting of the alloy, new cracks

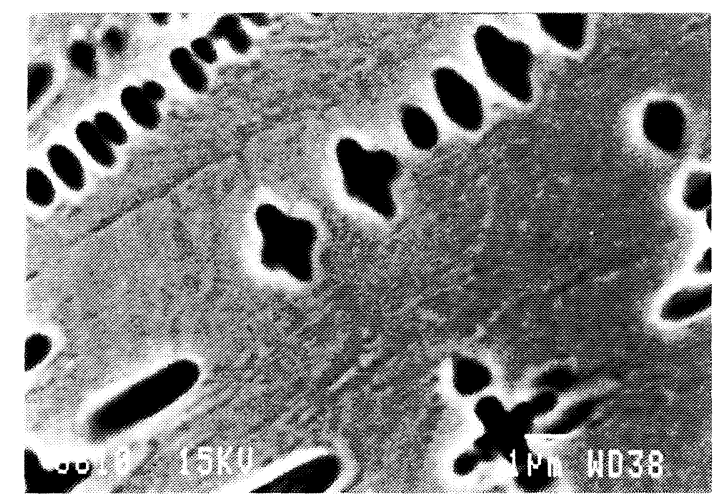

FIG. 12. - SEM micrograph of a cross section of a sample $180 \mu \mathrm{m}$ thick laser treated at $5,952 \mathrm{~mm} / \mathrm{min}$ showing amorphous interdendritic areas.

FIG. 12.- Micrografía de las areas amorfas interdendríticas en una muestra de Ni-P con un espesor de $180 \mu \mathrm{m}$ tratada a una velocidad de 5.952 $\mathrm{mm} / \mathrm{min}$.

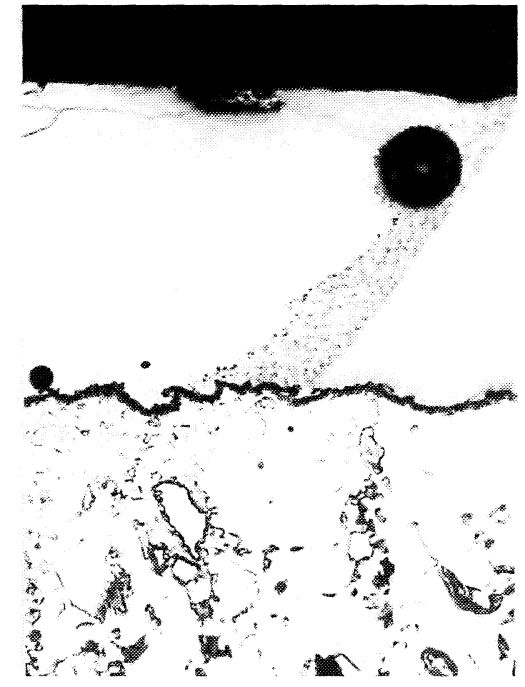

FIG. 13.- Metallographic observation of a cross section of a sample $180 \mu \mathrm{m}$ thick treated at 2,520 $\mathrm{mm} / \mathrm{min}$ showing globular precipitated in the heat affected zone. $\times 200$.

FIG. 13.- Sección transversal de una muestra de $\mathrm{Ni}$-P con un espesor de $180 \mu \mathrm{m}$ tratada a una velocidad de $2.520 \mathrm{~mm} / \mathrm{min}$ en la que se muestra la precipitación globular en la zona afectada térmicamente. $\times 200$.

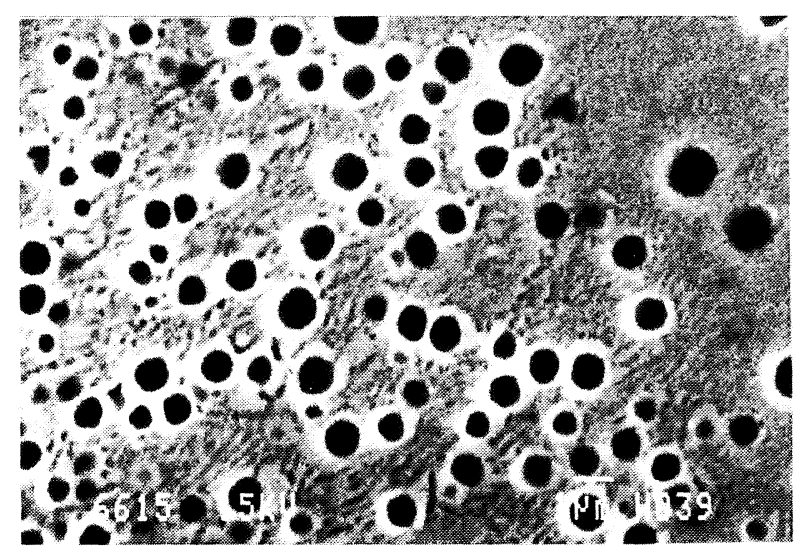

FIG. 14.- SEM micrograph showing globular precipitation in a sample $180 \mu \mathrm{m}$ thick treated at $5,952 \mathrm{~mm} / \mathrm{min}$

FIG. 14.- Micrografía de la precipitación globular de una muestra de Ni-P con un espesor de $180 \mu \mathrm{m}$ tratada a una velocidad de $5.952 \mathrm{~mm} / \mathrm{min}$.

appear (Fig.15) because of the stresses generated by the volume changes during solidification. Nevertheless, for the thicker coating alloy laser treated at the higher scanning rate, these cracks are thinner and they do not penetrate into the substrate. 


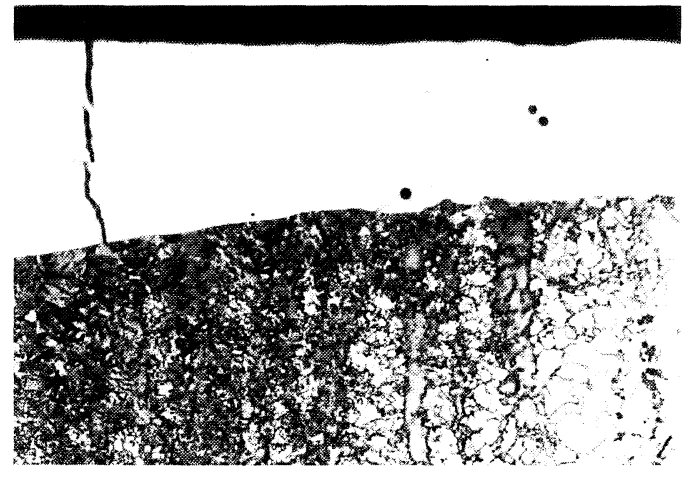

FIG. 15.- Metallographic cross section showing cracks in a sample $180 \mu \mathrm{m}$ thick at $1,180 \mathrm{~mm} / \mathrm{min}$. $\times 100$.

FIG. 15.- Sección transversal de una muestra de $\mathrm{Ni}-\mathrm{P}$ con un espesor de $180 \mu \mathrm{m}$ tratada a una velocidad de $1.180 \mathrm{~mm} / \mathrm{min}$ en la que se muestran grietas. $\times 100$.

\section{DISCUSSION}

Laser treatment has affected both the mild steel substrate structure and the electroless Ni-P coating. In the steel substrate, microstructure modifications have occurred during laser treatment by heating effect, through solid state phase transformations. Near the melt zone, the temperature reached during heating was high enough to promote the transformation $\alpha \rightarrow \gamma$ with quenching to martensite during later cooling. In the vicinity of the unaffected substrate, the temperature reached is located in the $\alpha-\gamma 2$-phase field and because of the heating, the pearlite -only stable at low temperatures- is transformed to austenite that quenches to martensite during the cooling. However, the ferrite in bands with low carbon content only presents a modification in the grain size.

The solidification process starts with a plane front composed by a solid solution of $\mathrm{Fe}-\mathrm{Ni}$ in which phosphorous is rejected to the melt coating alloy and also penetrates the steel substrate producing a metal liquid attack. The reason for this phosphorous segregation is that the phosphorous is not soluble either nickel nor in iron, but there is a full solubility between iron and nickel. When the solidification rate raises, the plane front becomes unstable disappearing and dendritic growth of Fe$\mathrm{Ni}$ solid solution appears. Again the phosphorous is segregated to the interdendritic areas. When the solidification process finishes the interdendritic areas have a higher phosphorous content and the composition of an eutectic of $\mathrm{Fe}-\mathrm{Ni}$ solid solution and a mixed phosphide: $(\mathrm{Fe}, \mathrm{Ni})-(\mathrm{Fe}, \mathrm{Ni})_{3} \mathrm{P}(8)$.
The different solid phases and the solidification mechanism proposed take place for all the samples laser treated independently of the conditions tested, except in the singular case of a coating thickness of $180 \mu \mathrm{m}$ and a scanning rate of $5,952 \mathrm{~mm} / \mathrm{min}$. In this case, there is almost no dilution with the steel substrate, the amorphous structure is kept and only a little degree of crystallization occurs.

The initial coating thickness and the laser scanning rate have an influence on the shape, extent and size of the different structures resulting from the solidification process.

In figure 16 the thickness of the melted coating is represented versus the laser scanning rate for the samples with the maximum and minimum initial coating alloy thickness. It could be seen that for samples with $45 \mu \mathrm{m}$ thickness, the melted coating thickness is about five times the initial one for a low scanning rate. Here the interaction time has been so high that crystallization has been complete and a strong effect of dilution with the base metal has taken place. The higher the laser scanning rate, the lower the dilution with the steel and the degree of crystallization.

The low laser scanning rates have also a negative influence on the dilution effect with steel and the degree of crystallization for samples with the maximum coating alloy thickness $(180 \mu \mathrm{m})$.

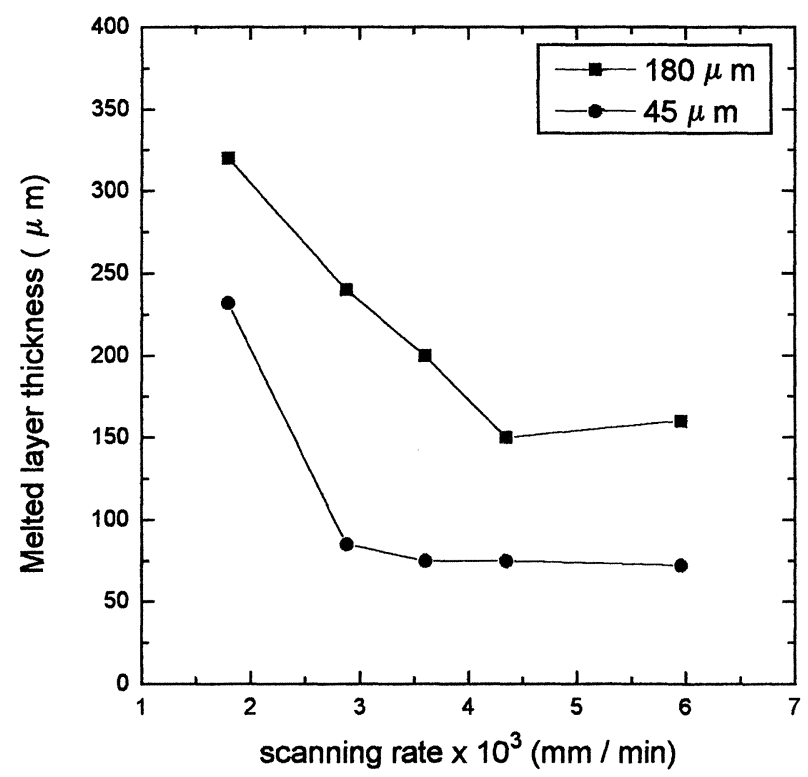

FIG. 16.- Thickness of the melted layer versus laser scanning rate for $45 \mu \mathrm{m}$ and $180 \mu \mathrm{m}$ thick samples.

FIG. 16.- Espesor de capa fundida frente a la velocidad de barrido para muestras con espesores de 45 y $180 \mu \mathrm{m}$. 
The optimum conditions tested are reached for samples with $180 \mu \mathrm{m}$ laser treated at 5,952 $\mathrm{mm} / \mathrm{min}$. In this case the melted coating keeps its initial thickness and the degree of crystallization is minimum, the adherence is good and the coating has no cracks.

In a further research it should be considered that to block the dendritic growth not only the laser scanning rate must be increased but also the laser incident beam power -a parameter not studied in the present paper- could be decreased in order to get enough heating effect to melt the coating but the minimum perturbation of the substrate material.

\section{CONCLUSIONS}

The beneficial effects of the laser melting treatment employed to improve the quality of $\mathrm{Ni}-\mathrm{P}$ surface alloys on mild steel depend on the laser processing conditions -especially on the laser scanning rate- and the initial coating alloy thickness.

In the dendritic solidification, when the laser scanning rate increases a progressive refinement of the structure takes place that could even block totally the dendritic growth. If high enough beam scanning rates are reached, the later cooling rate will be so high that it will not allow the diffusion of atoms to form the equilibrium phases and an amorphous structure could be obtained.

\section{Acknowledgements}

The authors gratefully acknowledge the financial support received from the "Comision Interministerial de Ciencia y Tecnología" (Proyecto de investigación MAT92-0395).

\section{REFERENCES}

(1) Zarzycki, J. Glasses and Amorphous Materials. Materials Science and Technology. Vol. 8. VCH, 1991.

(2) KURZ, W. and FisHER, D.J. Fundamentals of Solidification. Trans. Tech. Publ. Aedermansdorf (Suiza), 1986.

(3) Brenner, A., Couch, D.H. and Williams, E.K. J. Res. Nat. Bur. Stand., 44, 1950: 109.

(4) Rajagopal, C., Mukherjee, D. and Rajagopalan, K.S. Met. Finish., 59, 1984.

(5) Coratuotolo, J. and Tramontana, D. Electroless Plating. American electroplaters and surface finishers, AESF, 1992: 207-229.

(6) Ruiz, J., Fernández, B.J., Bello, J.M., Sanz, P. and ZuBIRI, J.F. Rev. Metal Madrid, 26 (6), 1990: 374-385.

(7) Massalski, T.B. Binary Alloys Phase Diagrams. ASM, Metals Park, Ohio. (EE.UU.). Vol. I, 1986.

(8) Renaud, L., Fouquet, F., Elhamdaoui, A., Millet, J.P., Mazille, H. and Crolet, J.L. Acta Metall., 38, 1990: 1.547-1.553. 